\title{
MICROFORAMINIFERS OF THE CALLOVIAN AND CRETACEOUS SEDIMENTS OF UKRAINE
}

\author{
O.A. Shevchuk ${ }^{1}$, O.D. Veklych ${ }^{2}$, Yu.B. Dorotyak ${ }^{3}$
}

(Recommended by doctor of geological-mineralogical sciences M.M. Ivanik)

${ }^{I}$ Institute of Geological Sciences of NAS of Ukraine, Kyiv, Ukraine, E-mail: hshevchuk@ukr.net Candidate of geological sciences, senior research worker.

2 Institute of Geological Sciences of NAS of Ukraine, Kyiv, Ukraine, E-mail: veklych_od@i.ua Junior research worker.

3 Institute of Geological Sciences of NAS of Ukraine, Kyiv, Ukraine, E-mail: dorotyak@mail.ru Junior research worker.

For the first time in Ukraine in Callovian and Cretaceous sediments the microforaminifers were found. They were established during the study of Mesozoic sediments palynocomplexes of 17 outcrops and wells Volyno-Podolska plate, Ukrainian Shield, the outstirts of Donbass, Priazov, Black Sea basin and the Crimea. The method of preprocessing sediments for microforaminifers was corrected. The paleontological characteristics Callovian, Berriasian, Aptian, Albian, Cenomanian, Turonian, Coniacian, Campanian and Maastrichtian deposits for microforaminifers showed in four phototables is augmented.

Key words: microforaminifers, Callovian and Cretaceous sediments, Ukraine.

\section{МІКРОФОРАМІНІФЕРИ КЕАОВЕЙСЬКИХ ТА КРЕЙАОВИХ ВІАКАААІВ УКРАЇНИ}

\section{О.А. Шевчук ${ }^{1}$, О.Д. Веклич ${ }^{2}$, Ю.Б. Доротяк ${ }^{3}$}

(Рекомендовано д-ром геол.-мінерал. наук М.М. Іваніком)

I Iнститут геологічних наук НАН Украӥни, Київ, Україна, E-mail: hshevchuk@ukr.net Кандидат геологічних наук, старший науковий співробітник.

2 Інститут геологічних наук НАН Украӥни, Київ, Украӥна, E-mail: veklych_od@i.ua Молодиий науковий співробітник.

3 Інститут геологічних наук НАН Украӥни, Київ, Україна, E-mail: dorotyak@mail.ru Молодиий науковий співробітник.

Вперше на території України в келовейських та крейдових відкладах виявлено мікрофорамініфери. Вони встановлені при вивченні палінокомплексів у мезозойських відкладах 17 відслонень та свердловин Волино-Подільської плити, Українського щита, окраїн Донбасу, Приазов'я, Причорноморської западини та Криму. Відкореговано методику первинної обробки порід для мікрофорамініфер. Доповнена палеонтологічна характеристика келовейських, беріаських, аптських, альбських, сеноманських, туронських, коньякських, кампанських та маастрихтських відкладів за мікрофорамініферами, що відображені у чотирьох фототаблицях.

Ключові слова: мікрофорамініфери, келовейські та крейдові відклади, Україна.

(c) O.A. Shevchuk, O.D. Veklych, Yu.B. Dorotyak, 2015 


\title{
МИКРОФОРАМИНИФЕРЫ КЕААОВЕЙСКИХ И МЕАОВЫХ ОТАОЖЕНИЙ УКРАИНЫ
}

\author{
Е.А. Шевчук ${ }^{1}$, Е.Д. Веклич ${ }^{2}$, Ю.Б. Доротяк ${ }^{3}$
}

(Рекомендовано д-ром геол.-минерал. наук М.М. Иваником)

${ }^{1}$ Институт геологических наук НАН Украины, Киев, Украина, E-mail: hshevchuk@ukr.net Кандидат геологических наук, старший научный сотрудник.

2 Институт геологических наук НАН Украины, Киев, Украина, E-mail: veklych_od@i.ua Младиий научный сотрудник.

3 Институт геологических наук НАН Украины, Киев, Украина, E-mail: dorotyak@mail.ru Младиий научный сотрудник.

Впервые на территории Украины в келловейских и меловых отложениях выявлены микрофораминиферы. Они установлены при изучении палинокомплексов в мезозойских отложениях 17 обнажений и скважин Волыно-Подольской плиты, Украинского щита, окраин Донбасса, Приазовья, Причерноморской впадины и Крыма. Откорректировано методику первичной обработки пород для микрофораминифер. Дополнена палеонтологическая характеристика келловейских, берриаских, аптских, альбских, сеноманских, туронских, коньякских, кампанских и маастрихтских отложений данными по микрофораминиферам, что отображено в четырех фототаблицах.

Ключевые слова: микрофораминиферы, келловейские и меловые отложения, Украина.

\section{Introduction}

Today, only few experts determine Mesozoic foraminifera in thin sections and macerates. Ukraine do not have such specialists. Therefore, we summarized literature data, which covers the study of microforaminifers of Mesozoic rocks of different continents, studied and described the material collected on the territory of Ukraine.

A common feature for all foraminifera (secretion and agglutinated) is the presence of pseudochitinous base of their shells. Pseudochitinous lining (membrane, layer) is a thin layer of organic matter that forms the inner layer of foraminifera shells. The thickness of the pseudochitinous membrane in different kinds is different, so the findings do not correspond to the actual composition of foraminifera in the rock. Sometimes microforaminifers do not have the membrane but only the loculum substituted by rock. Microforaminifers - thick or thin fine "shell" forms of foraminifera from 30 to 150 , sometimes up to 250 microns in size [Петросьянц и др., 1990]. Microforaminifers are often present in palynological samples as fragments that can be presented as the whole (or almost whole) samples of the original loculum, and as individual loculum or two, three or more connected loculums. Microforaminifers have an organic shell - pseudochitine that is by the chemical composition close to exine of spores, pollen and some mushrooms - close to albuminoid protein matter, similar to keratin by the contents of sulfides. Acid resistance is explained by the composition of membrane or inner walls of individual microforaminifera loculums.

\section{History of the study}

The term microforaminifers was introduced by O. Wetzel [Wetzel, 1957] for the linings of young or undeveloped parts of foraminifera and their chitinous shells. The microforaminifera objects are mentioned in the work of L. WiIson and W. Hoffmeister [Wilson, Hoffmeister, 1952]. They found the microforaminifers in palynological samples. Due to their small size (according to most authors less than $150 \mu \mathrm{m}$ ) the term microforaminifers became common, but many people considered it inappropriate to use the name and offered other synonyms: scytinascia, basal membrane, chitinous lining, chitinous microforaminifers, tectinoid primitive foraminifera and tectinoid linear procula, nanoforaminifers, palynoforaminifers, microforaminifera lining, pseudochitinous microforaminifers [Dełk, 1964; Milk, Sotak; 1998; Петросьянц и др., 1990; Stancliffe, 1996; Глузбар, 1983; Lantos et al., 1996]. All these names have been caused by problems with the uncertainty of foraminifera chemical composition, biogenic original and the taphonomic conditions. In the 
paper of N. Pantic, Z. Bajraktarevic [Pantic, Bajraktarevic, 1988] the authors found palynoforaminifers and ascertained that nanoforaminifers are distinguished from palynoforaminifers because they are carbonate and silicic nanofossils. A.D. Cohen, A.L. Guber found where in palynological species appear pseudochitinous "microforaminifers" [Cohen, Guber, 1968]. They studied the Quaternary foraminifera from brackish water peat in southwestern Florida. They dipped each type in a small amount of $30 \%$ hydrochloric acid and watched its influence through binocular microscope with a measuring scale. The researchers concluded that not every kind has visible pseudochitinous remains. The authors calculated the number of loculums and on this basis concluded that the calcite and hydrochloric acid interaction resulted in organic base release which compressed, and the size reducing reached $40 \%$.

Although the origin of "pseudochitinous microforaminifers" is experimentally shown but the doubts remain. There is no assurance that along with the common foraminifers that appear as a result of rock processing by salt or hydrofluoric acid there are similar to them residues without mineral shell or lost it on the stage of diagenesis. This statement of course contradicts the idea that chitine and pseudochitine are unstable and easily destroyed by bacteria if they are not protected by an inorganic matter. It is known that after the death of the animal the pseudochitinous base of shell decays [Глузбар, 1983] and it is required special conditions for this natural process not to happen. Moreover, pseudochitine (tectine), compared with chitine of arthropods, is soluble in mineral acids (eg. in 10-15\% hydrochloric acid and alkalis) [Глузбар, 1983]. This is contrary to the obvious number of pseudochitinous microforaminifers findings. Ukrainian palynologists always marked the microforaminifers in palinospectrums of different ages [Глузбар, 1983; Фуртес, 1987; Чорна, 1972; Федорова, 2006], but they were not investigated in detail and rarely showed on phototables.

The stratigraphic significance of microforaminifers is controversial, some scientists reject their biostratigraphic value [Глузбар, 1983], the other scientists use them for partition of sections [Лебедева, Никитенко, 1998; Никитенко, Глинских, 2006]. The stratigraphic distribution range of microforaminifers - Paleozoic - Pleistocene.
There is no doubt in the importance of microforaminifers for clarifying the conditions in which sedimentation took place, they can be used to characterize the different environments of marine sedimentation. K. Faegri, J. Iversen in 1950 said that chitine shell remaining after the destruction of calcareous shells of foraminifera, can only serve as proof of the marine origin of sediments [Петросьянц и др., 1990]. The 90 th century studies indicate that the species with the coarse primary loculum were confined to the warm waters with good light to surface waters. Instead, the species with the small original loculum indicate the growth suppression in deep water conditions [Петросьянц и др., 1990]. Thus, the morphological differences of embryonic and juvenile stages also allow to reconstruct the environmental conditions.

\section{Materials and Methods}

In our practice we tried to investigate microforaminifers for the first time. It was created the group of scientists from different fields: the palynologist, and Jurassic and Cretaceous microfaunists. The first task of palynologist was the preprocessing of rocks and detection of faunal remnants of all ages in macerates. There were studied the rocks of outcrops as well as from wells of Callovian age, Early and Late Cretaceous of Ukraine. Moreover, we compared the microforaminifers with the shell of organic matter (pseudochitine) from different lithological composition rocks. The second task of microfaunists was to determine the types of microforaminifers, study their systematic diversity, and establish the differences between complexes of microforaminifers of all ages and their comparison with normal size foraminifers in the samples of the same age.

The material for our study were Jurassic and Cretaceous samples, which were selected from 17 outcrops and wells in Ukraine: VolynoPodilska Plate - borehole 42, drilled near the village of Mala Hlusha, Kamin-Kashyrsky district, Volyn region; borehole 31, drilled near the city of Lutsk; outcrop near the village of Zavadivka, Ternopil region; Ukrainian shield - four outcrops in Kaniv district - Melanchyn Potik, Malyi Pekarskyi Yar, Kholodnyi Yar, and Kostyanetskyi Yar and borehole 8562, drilled near the village of Polohy, Pereyaslav-Khmelnytskyi district, Kyiv region; Donbass margins - outcrop 
near the villages of Rovenky and Hlafyrivka, Lugansk region; outcrop $1 \mathrm{~km}$ from the village of Zbirne (Krutenka ravine) Lutuhyn district, Lugansk region; outcrop near the town of Heorhiyivka (Konoplyanka ravine) Lugansk region; Azov region - borehole 97, drilled in the eastern part of the village of Pokrovo-Kireyevo; Black Sea basin - boreholes 0121 and 0123 near the Bashtanka city, Mykolayiv region; and Crimea - outcrop near the village of Krasnoselivka, Tonasu river (Berriasian), Belohirsk district, outcrop near the Kacha river, Verhorichchya city (upper section), Bakhchisaray district and borehole Simferopol-1, drilled in the foothills of the Crimea $1 \mathrm{~km}$ to the south-east from the village of Dymytrovo (Fig. 1).

Jurassic and Cretaceous sediments of these areas previously have been stratified by O.A. Shevchuk on the results of palynological studies (spores, pollen, dinocysts) [Шевчук, 2006, 2009, 2012; Доротяк и др., 2009; Стратиграфія..., 2013].

Maceration of species was performed by separation standard methods proposed by V.P. Hrychuk [Методические..., 1986], but with some amendments. It is believed that organic layers of very fine foraminifera were coloured by Fe-oxide naturally during the early diagenesis. It protected them from destruction and made them visible in macerates [Milk, Sotak, 1998]. Microforaminifera linings or membranes are rarely preserved. In the classical method of foraminifera identifying they can be lost during the washing off because they are too fine. But microforaminifers can be removed using corrected initial processing of rocks for palynological analysis. The preparing procedure is complex. The dense rock was slightly comminuted, and more often macerated in water for one day. The decarbonatization of carbonate rocks was conducted in two phases: quenching with $30 \%$ hydrochloric acid and boiling in dilute hydrochloric acid. Microforaminifera lining is removed from the sand and clay rocks by dissolution of rocks with fossils in a diluted hydrochloric acid (10-15\%), as the result the shell dissolves. After frothing the thin "glacial" membrane formed, which was destroyed by undiluted rectified alcohol. Then the rock was immersed in $40 \%$ hydrofluoric acid and boiled for 10 minutes. Then the rock was poured by hydrochloric acid again. In primary treatment an important role plays the lithological composition of rock. We conducted the

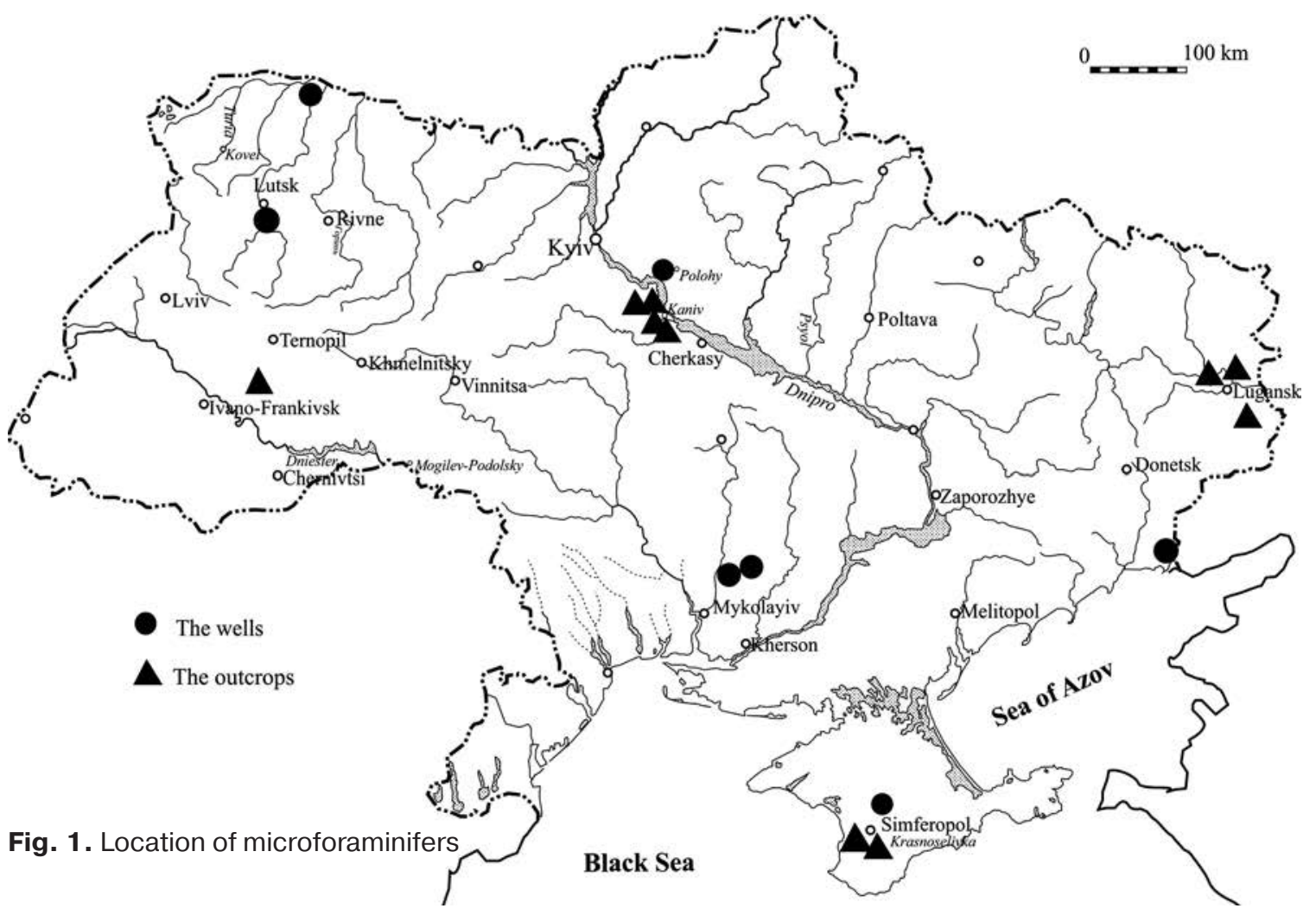


additional heat treatment of carbonate rocks in hydrochloric acid, for some species the dispersion was carried, at the end - a heavy liquid separation. After each procedure the samples were repeatedly washed with distilled water at intervals of 2-3 hours. Alkalis and nitric acid, mostly were not used. We also conducted an experiment, emphasized by E.A. Gluzbar [Глузбар, 1983], and repeated maceration of samples of Upper Cretaceous (CenomanianConiacian) sandy limestone, calcareous sandstone and chalk from the borehole 42 without separation in heavy liquids. The fragments of limestone and chalk were gradually dissolved in hydrochloric acid to the total destruction. Microforaminifers were recorded in these samples in large amounts. But the most numerous pseudochitinous microforaminifers were found in clays and siltstones (Callovian) borehole 8562, where all the technique stages were used.

In clay sediments of borehole 97 the microforaminifers were found in almost all studied samples. When macerating of these rocks there was used the method proposed by T.V. Shevchenkо [Шевченко, 2006]. When processing all standard steps were used and in addition the samples were boiled in hydrofluoric acid. In carbonate sediments of borehole 42 the microforaminifers were found in all palynosamples from Cenomanian to Coniacian. In primary treatment of these rocks we used only the samples in hydrochloric acid, then the finely dispersed membrane was taken and studied under a microscope. Centrifuge and separation in heavy liquids were not involved.

We conducted laboratory studies and ascertained that the number of microforaminifers species that were saved after treatment with hydrochloric acid (chitinoid microforaminifers) is very small, but the long heat treatment with hydrofluoric acid (or hydrochloric - depending on lithology) provided the strength of these species and microforaminifers "formed" - decreased. Exsept microforaminifers (nanoforaminifers) after this treatment, in palynospectra the fungal spores (conidia mostly) are observed in large quantities.

Diagnosis and measurement of microforaminifera shells in macerates were conducted on biological microscope MBI- 6 or Erhaval. A measurement of microscopic objects was conducted by special nozzles to microscopy and advanced computer programs. For viewing under a microscope the macerates were used rather than regular samples. This enabled us to move the microscopic foraminifera species. Further, the microfaunists made a general idea of the morphology of shells. Then they divided them on features specific to families and genera. The nature of wall and structure type of shells are the most important features to distinguish a major taxon. The presence and the division nature of loculums is a feature of family and genera. The form of shell, cross-section nature, loculum shape, their number, septal sutures nature are generic and specific features. The nature and position of the mouth are basically fungible, but the structure details have species character. The further study allows us to determine the details of the structure. They may be the main distinguishing features of some species of Jurassic and Cretaceous.

\section{Research results}

The studied microforaminifers have a different form. As the shell is not preserved, we can not argue whether these forms are secretion or agglutinated, so we used the classification of M.H. Deak [Deak, 1964]. In the palynological samples were found all three types identified by M.H. Deak: the first - single row straight form (Table I, Fig. 1; Table III, Fig. 7), the second - a spiral drawed in one or three planes (Table I, Fig. 2-11; Table II, Fig. 1-9; Table III, Fig. 4, 6, 8-12; Table IV, Fig. 2, 3, 7) and the third - spherical and coiled loculums that make each other (Table I, Fig. 12; Table III, Fig. 5; Table IV, Fig. 1, 4-6). These pseudochitinous microforaminifers are well developed ("adult") shells consisting of 5-12 loculums. Another subtype of the second type can be microforaminifers that could have the initial loculum (and their lining), but after the primary processing they were dissolved. Therefore, these forms when the shells dissolved have voids in the center (Table III, Fig. 7, 12, maybe Fig. 11) and are similar to the Albian species Trochiliascia cuvillieri Deak, which is defined by Loeblich A.R., Jr., and Tappan H. [P. 212, PI. 846. Fig. 11, Loeblich, Tappan, 1988]. This subtype is found only in Cretaceous sediments. Also there were found 3 microforaminifera samples of the fourth type - straight, sometimes two row, that are substituted by silicon rock (Table III, Fig. 1-3). These microforaminifera specimens were studied in chemical laboratory of PDRHP "Piv- 


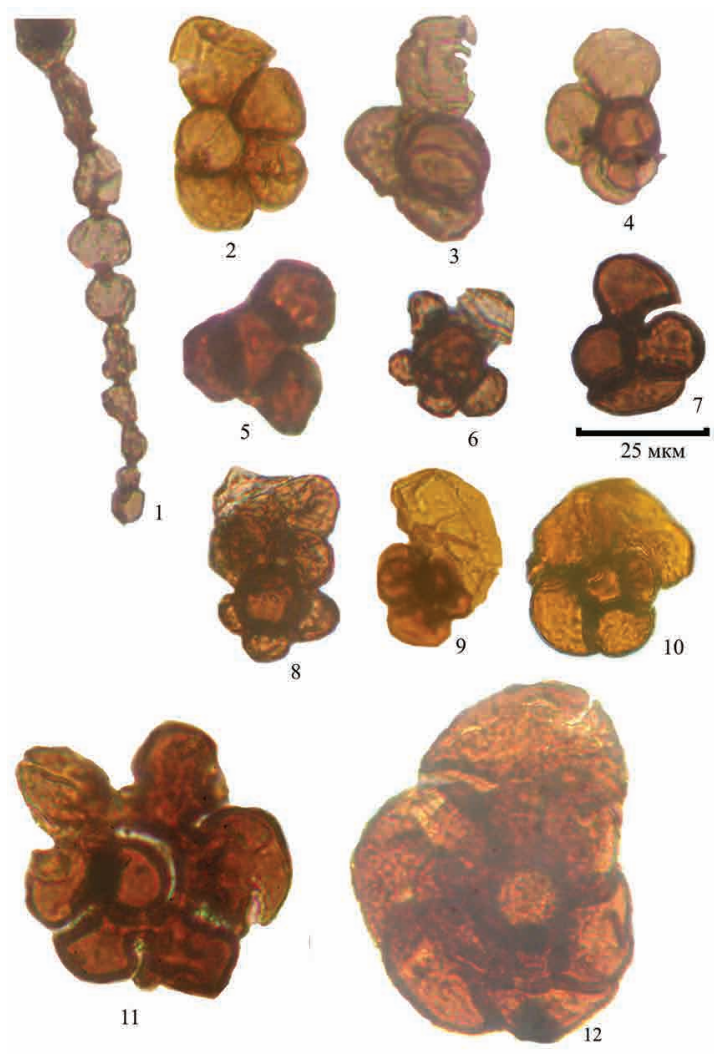

Table I. Microforaminifers of the Callovian sediments of Ukraine. Increasing x650

Fig. 1. Subreophax cf. multilocularis Haesler, borehole 8562, (Callovian). Fig. 2. Subtrochammina cf. constricta Haeus, borehole 8562 (Callovian). Fig. 3, 4. Subtrochammina cf. globigeriniformis (Parker et Jones), borehole 8562 (Callovian). Fig. 5-9. Subtrochammina sp., borehole 8562 (Callovian). Fig. 10. Subrecurvoides cf. disputabilis Dain., borehole 8562 (Callovian). Fig. 11. Subhaplophragmoides aff. nonioninoides (Reuss), near the town of Kaniv (Callovian). Fig. 12. Subtrochammina cf. kumaensis Levina, near the town of Kaniv (Callovian)

nichgeologiya". It should be noted that these forms were found in samples which are not applied in a heavy liquid separation. All other specimens had the pseudochitinous shell. Also there was found the multi-vertical uniaxial microforaminifera of Nodosaria type (Table III, Fig. 13), which can not be attributed to the described four types (not seen in classifications of M.H. Deak and R.P.W. Stancliffe), so we have singled out it as a fifth type.

The main problem in microforaminifers systematic position study is that only the inner organic layer of shells is preserved and we do not know which was the outer wall - agglutinated
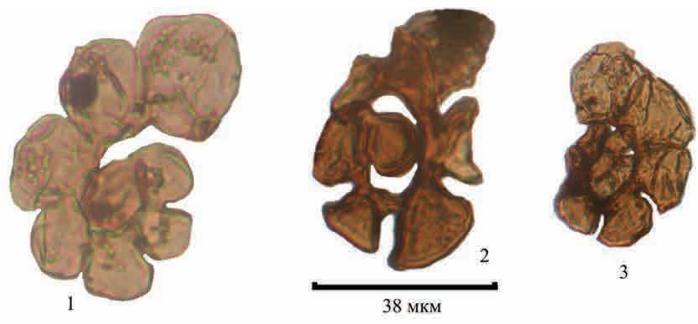

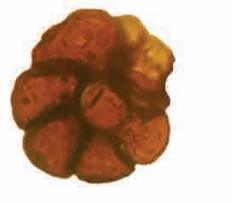

4
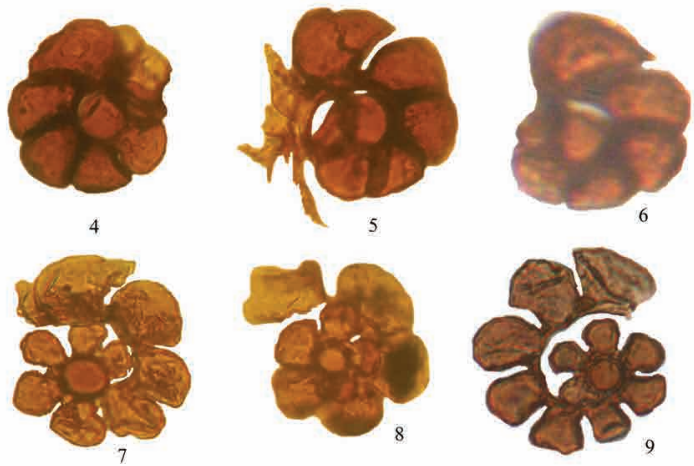

Table II. Microforaminifers of the Callovian sediments of Ukraine. Increasing x 650

Fig. 1-3. Subhaplophragmoides cf. canariense Orb., borehole 8562 (Callovian). Fig. 4-6. Subkutsevella cf. haplophragmoides (Fur. et Pol.), borehole 8562 (Callovian). Fig. 7-9. Subtrochammina ef. inflata (Montagu), borehole 8562 (Callovian)

or calcareous. The microforaminifers found are very small, ranging from 30 to 130 microns. The most common explanation for this is that they represent juvenile forms. However, they may represent a dwarf forms of adults living in poor conditions. We have studied the adult foraminifera shells in the same samples. Therefore, we believe that as there are the foraminifera lining and reduced in the initial processing foraminifera loculums, then the shells were slightly larger. But there are the representatives of dwarf forms. In determining the microforaminifers we followed the modern classification of Jurassic and Cretaceous foraminifera. Therefore, we believe that the organic remains of even very small foraminifera should be considered in the overall system of foraminifera, without creating a separate form classification. And if the names of generic microforaminifers taxa will repeat the name of normal size foraminifera, in order to avoid confusion, we decided to use the proposed by N.K. Lebedeva and B.L. Nikitenko [Лебедева, Никитенко, 1998] prefixes Sub- and Micro-. One of the meanings of "Sub-" in Latin is 


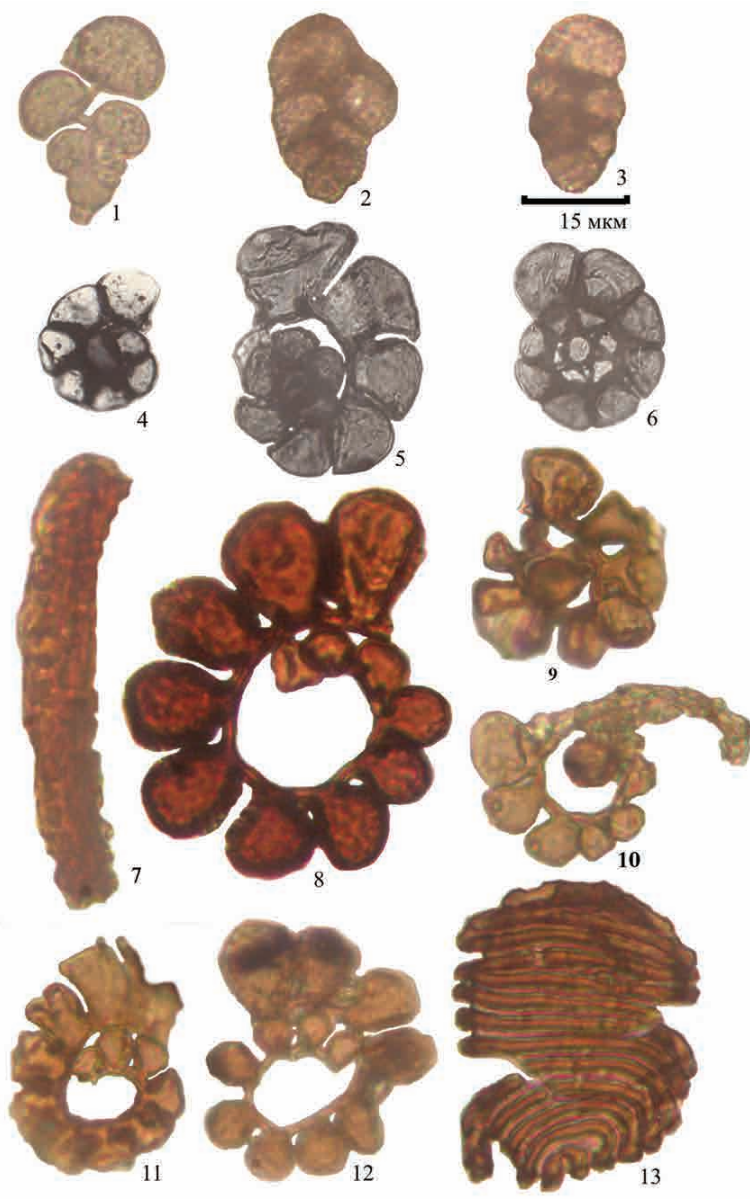

Table III. Microforaminifers of the Cretaceous sediments of Ukraine. Increasing x650

Fig. 1. Subheterohelix cf. globulosa (Ehr.), outcrop near the villages of Rovenky and Hlafyrivka (Turonian). Fig. 2. Subgaudrinopsis cf. plotnikovae Loebl. et Tapp., (borehole Simferopol-1), (Albian-Cenomanian). Fig. 3. Subgaudryinella cf. umokderensis Aleks., Crimea (outcrop near the Kacha river) (Aptian). Fig. 4. Subhedbergella cf. globigerinellinoides (Subb.), borehole 0121 (Albian). Fig. 5. Subtrochammina cf. nana (Brady), borehole 0123 (Aptian). Fig. 6. Subhedbergella cf. planispira (Tapp.), borehole 0121 (Albian). Fig. 7. Subsherochorella cf. minuta (Tapp.), borehole 97 (Maastrichtian). Fig. 8. Subtrochiliascia cf. cuvillieri Deak, borehole 42 (Cenomanian). Fig. 9. Subknasteria cf. spiralis Macko, borehole 97 (Maastrichtian). Fig. 10. Fragment of the microforaminifers, borehole 97 (Maastrichtian). Fig. 11. Subhemicyclammina cf. sigali Maync, borehole 97 (Maastrichtian). Fig. 12. Subtrochiliascia sp., borehole 97 (Maastrichtian). Fig. 13. Subspirocyclina cf. choffati MunierChalmas, borehole 42 (Coniacian)

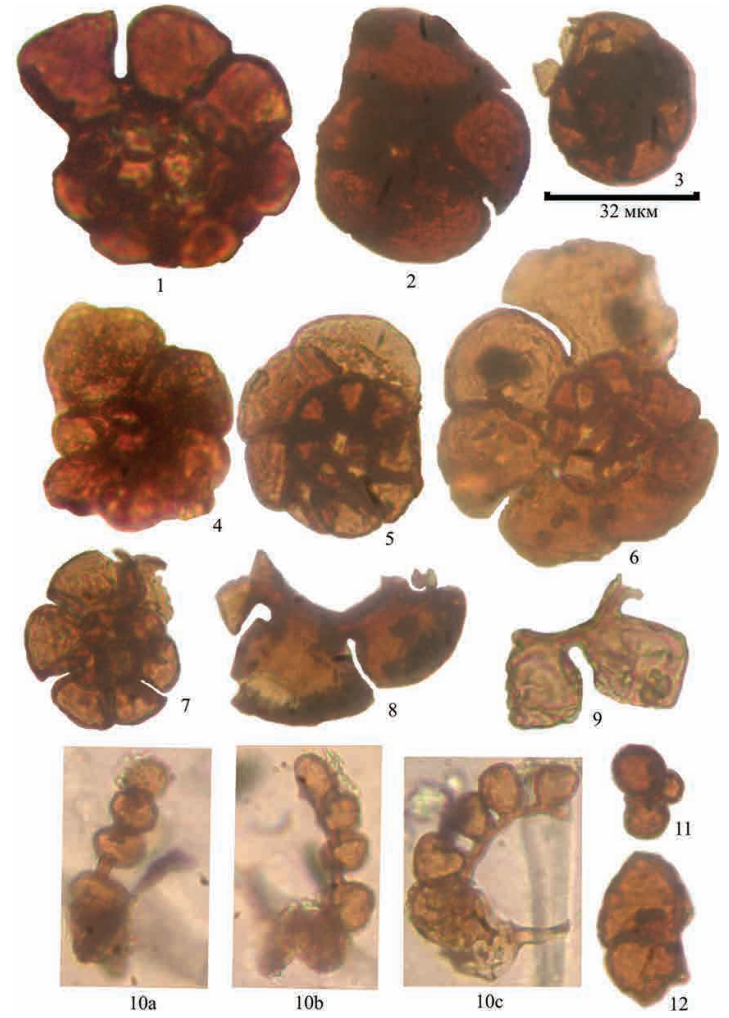

Table IV. Microforaminifers of the Cretaceous sediments of Ukraine. Increasing x650

Fig. 1. Submarginotruncana cf. marginata (Reuss), borehole 42 (Coniacian). Fig. 2. Subvalvulineria $\mathrm{cf}$. nonioninoides Bandy, borehole 97 (Maastrichtian). Fig. 3. Subgyroidinoides $\mathrm{cf}$ turgidus (Hag.), borehole 97 (Maastrichtian). Fig. 4. Subkutsevella cf. pseudogoodlandensis (Mjatl.), near the village of Krasnoselivka, Crimea (Berriasian). Fig. 5. Subglobotruncanita cf. stuarti (Lappar.), borehole 97 (Maastrichtian). Fig. 6. Subglobotruncana cf. lapparenti Brotz., borehole 97 (Maastrichtian). Fig. 7. Subglobotruncana cf. ventricosa White, borehole 97 (Mastrichtian). Fig. 8, 9, 11, 12. Fragment of the microforaminifers, borehole 97 (Maastrichtian). Fig. $10 a, b, c$. Fragments of the same microforaminifers with spherical cameras in different projections, borehole 97 (Maastrichtian)

"inside" or "under". Thus, the generic names of microforaminifers taxa will reflect the closeness to the genera of existing natural system foraminifera classification and at the same time by the prefix Sub- emphasize their size. We also offer to combine the microforaminifers in a common natural classification system with the simple foraminifera. In this case, you can use this group fully in solving problems of biostratigraphy and biofacial analysis. 
Given all the above described details of our research we supplemented the paleontological characteristics of Callovian, Berriasian, Aptian, Albian, Cenomanian, Turonian, Coniacian, Campanian and Maastrichtian deposits with data on microforaminifers (Fig. 2).
Microforaminifers found in Callovian deposits samples (borehole 8562, $145.25 \mathrm{~m}$ ), which are the lower part of Ichnyanska suite, composed of calcareous sandstone, siltstone and siliceous clays. There were found the microforaminifers Subhaplophragmoides cf. canariense

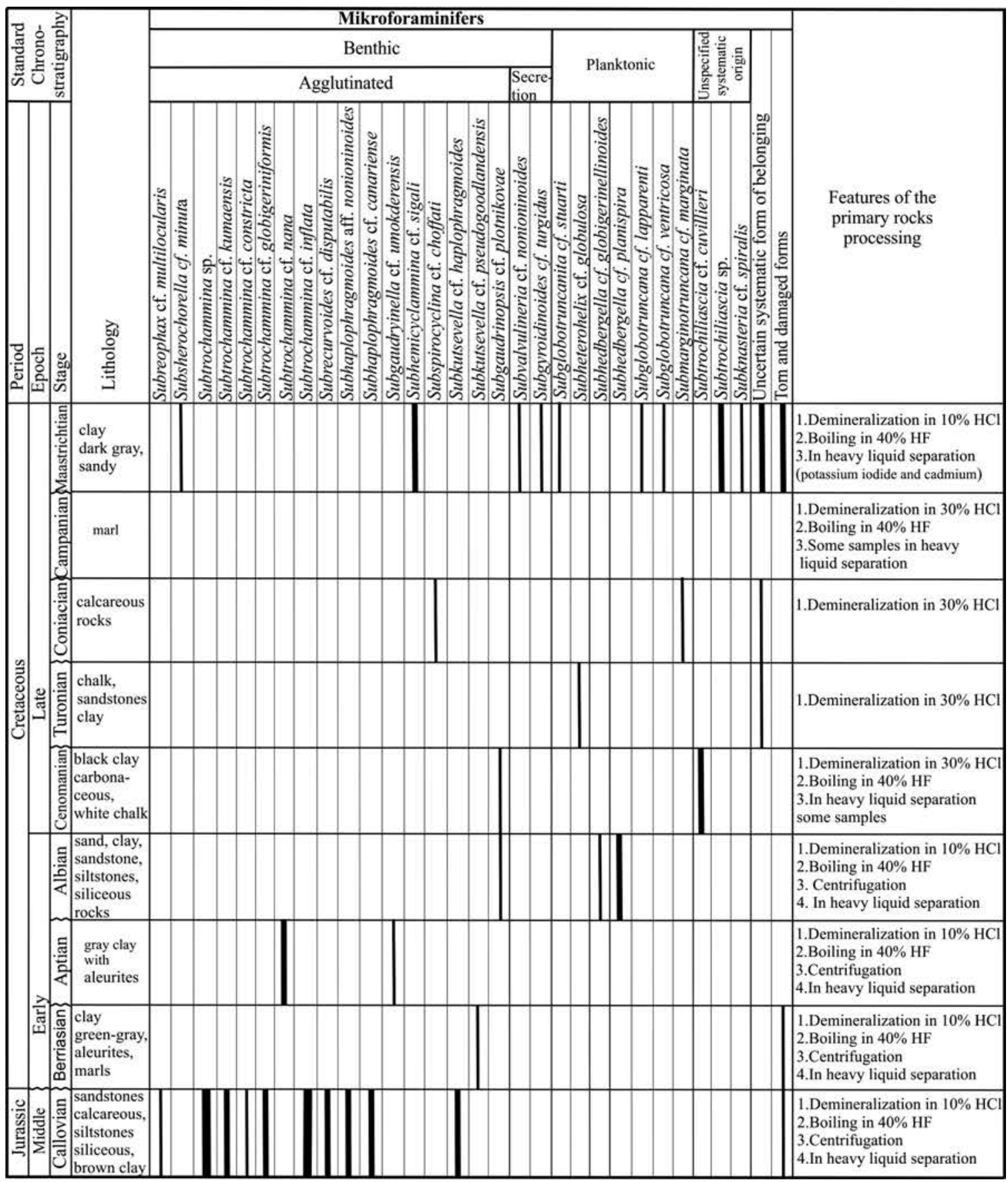

Legend:

1-3 pieces 20 3-10 pieces 20-30 pieces

Fig. 2. Stratigraphic distribution of typical microforaminifers in Jurassic and Cretaceous sediments of Ukraine 
Orb., Subkutsevella cf. haplophragmoides (Fur. et Pol.), Subtrochammina cf. inflata (Montagu), Subtrochammina cf. constricta Haeus and Subtrochammina spp. - in large quantities and Subtrochammina cf. globigeriniformis (Parker et Jones), Subrecurvoides cf. disputabilis Dain., Subreophax cf. multilocularis Haesler. There are the damaged form microforaminifers. These deposits were previously stratified by the authors according to palynological analysis and foraminifers [Шевчук, 2012; Стратиграфія..., 2013]. There wre established the Callovian palynological and dinocyst complexes characterizing the Ctenidodinium ornatum-Ctenidodinium continuum zone, which corresponds to the upper parts of lower and middle Callovian. There are acritarchs, plant tissues, pteridophytes spores in perispores, pigment flakes of insects (butterflies) and body parts of insects.

In Callovian sediments near the town of Kaniv (Melanchyn Potik, Malyi Pekarskyi Yar, Kostyanetskyi Yar), which are represented by the Ivanytska suite deposits, composed of light-brown to black clay were found the microforaminifers Subtrochammina cf. kumaensis Levina and Subhaplophragmoides aff. nonioninoides (Reuss). In these sediments there are the normal size foraminifera, bivalves, ostracods, sponge spicules, Callovian palynological complex, dinocysts, acritarchs and prasinophytes. The authors previously stratified these deposits by the flora and fauna groups as Upper Callovian [Стратиграфія..., 2013]. Мicroforaminifers were found in Late Albian sediments near the town of Kaniv in Kholodnyi Yar. The Albian deposits are represented by the Upper Albian sand with sandstone. Marine Albian sediments are composed of gray-green, glauconite, inequigranular sand with the layers and aggregates of greenish-gray glauconitic sandstone with remains of plants, wood debris and marine fauna. The microforaminifers Subhedbergella cf. planispira (Tapp.) and Subgaudryinopsis cf. plotnikovae Loebl. et Tapp. were found in these sediments. These deposits were previously stratified by palynological data (palynological complex, dinocysts) as Late Albian and according to spicule analysis as Cenomanian [Стратиграфія..., 2013].

In Berriasian deposits of Crimea near the village of Krasnoselivka (Tonas river and its tributaries) represented by the double-anchor suite (top), which is composed of greenish-gray thin-slabby clay, siltstone and marl were found the microforaminifers Subkutsevella cf. pseudogoodlandensis (Mjatl.). These deposits were previously stratified by authors as Berriasian [Стратиграфія..., 2013; Доротяк и др., 2009]. There were defined the normal size foraminifera, bivalves, numerous small gastropods, sea urchin needles in these deposits and Berriasian palynological and dinocysts complex corresponding to the area Pseudoceratium pelliferum (Berriasian), the rare forms of fungal spores of phycomycetes class - conidia.

In Aptian deposits of Crimea near the village of Verkhorichchya (Kacha river) represented by gray silty clays (Biasalinska suite) there are microforaminifers Subgaudryinella cf. umokderensis Aleks. In the representatives of the family Verneuilinidae, to which also belongs this genus, researchers observe the presence of pseudochitinous inner layer [Введение..., 1981]. The Aptian palynological complex is established [Шевчук, 2009; Стратиграфія..., 2013].

In Aptian sediments, borehole 0123 represented by sediments of Novooleksiyivska suite, which is composed of sandstones, siltstones, clays with limestone interlayers there are microforaminifers Subtrochammina cf. nana (Brady). The Novooleksiyivska suite corresponds to the Middle and Upper Aptian according to palynological complex and sometimes the Lower and Middle Albian according to foraminifers Hedberlella aptica Agal., Cibicidoides djaffarovi Agal. [Стратиграфія..., 2013].

In Albian sediments, borehole 0121 (247.8-250.5 m) represented by sediments of Zakhidnomykolayivska series, which is composed of marl, sandstone, clay, chert there are microforaminifers Subhedbergella cf. planispira (Tapp.) and Subhedbergella cf. globigerinellinoides (Subb.). These deposits were previously stratified by palynological (palynological complex, dinocysts, acritarchs) and microfauna data as Albian [Стратиграфія..., 2013].

In Cenomanian deposits of Crimea, borehole Simferopol-1 (3424-3425 m), which are represented by dark gray to black, clay, poor carbon, thin layered, dense shale there are microforaminifers Subgaudryinopsis cf. plotnikovae Loebl. et Tapp. These deposits were previously stratified by palynological data (palynological complex, dinocysts) as Cenomanian [Стратиграфія..., 2013]. There are also the fragments of sponge spicules and radiolarians. 
In Cenomanian sediments, borehole 42 , represented by the layers of inoceramus limestone there are microforaminifers Subtrochiliascia cf. cuvillieri Deak. These deposits were previously stratified according to palynological analysis [Шевчук, 2006; Стратиграфія..., 2013]. There were established the Cenomanian palynological and dinocyst complexes represented by Ovoidinium sp., Litosphaeridium siphoniphorum Cookson et Eisenack, Cribroperidinium intricatum Davey, Epelidosphaeridia spinosa Cookson and Hughes (Davey). There are also the spicules of sponges. In Turonian deposits of borehole 42 represented by the lower subsuite of Zdolbunivska suite, which is composed of white porous soft chalk there are microforaminifers of uncertain systematic status, maybe Subtrochiliascia sp. These deposits were previously stratified according to palynological analysis [Шевчук, 2006; Стратиграфія..., 2013]. There were established the Turonian palynological and dinocyst complexes. In Coniacian deposits of borehole 42 represented by the upper subsuite of Zdolbunivska suite, which is composed of white writing porous clay chalk there are microforaminifers Subspirocyclina cf. choffati Munier-Chalmas and Submarginotruncana cf. marginata (Reuss). These deposits were previously stratified according to palynological analysis [Шевчук, 2006; Стратиграфія..., 2013]. There were established the Coniacian palynological and dinocyst complexes characterizing the Subtilisphaera pontis-mariae zone, which corresponds to the upper Turonian - Coniacian.

In Turonian deposits, borehole $\mathbf{3 1}(68.20 \mathrm{~m})$, represented by writing chalk there are microforaminifers of uncertain systematic status. These deposits were previously stratified by palynological data (palynological complex, dinocysts) as Turonian [Стратиграфія..., 2013].

In Turonian deposits, outcrop near the village of Zavadivka, represented by the sediments of lower subsuite of Dubovetska suite which is composed of white chalky creamy limestone there are microforaminifers Subtrochiliascia sp. There are also the Turonian palynological and dinocyst complexes, and fossil remains of fungi - conidia. These deposits were previously stratified according to palynological analysis as Turonian [Стратиграфія..., 2013].

Cenomanian-Turonian deposits of Lugansk region near the village of Rovenky, section
Hlafyrivka (sample 33) are represented by Slovyanohirska suite that composed of sand and calcareous sandstones. It was thought that the Cretaceous section of the village of Hlafyrivka is of Cenomanian age. In calcareous sandstone L.M. Yakushyn defined the bivalve mollusc Nucula cf. pectinata Sow., according to which the age of these rocks is considered as Cenomanian. From this section O.A. Shevchuk showed the palynocomplex and dinocysts characteristic of Cenomanian. There are the microforaminifers Subheterohelix cf. globulosa (Ehr.). However, the studied characteristic species of normal size foraminifera complex indicate the Early Turonian age: Spiroplectammina cuneata Vass., Arenobulimina minima Vass., zonal index species - Globorotalites hangensis Vass., Gavelinella vesca (N. Byk), G. nana Ak., Brotzenella belorussica (Ak.). By zonal type there is the Globorotalites hangensis area, the top of the lower Turonian. This foraminifera zone corresponds to the upper part of macrofauna zone Inoceramus labiatus of lower Turonian subformation [Стратиграфія..., 2013]. There was determined the impoverished foraminifera complex represented by small shallow water coastal forms. The foraminifer's shells are poorly preserved and depressed. There are phosphate foraminifera and ostracods, fragments of bryozoans and sponges spicules, sea urchins needles, single radiolarians and shark teeth.

In Campanian sediments from the outcrop near the village of Zbirne (1 $\mathrm{km}$ from the village of Krutenka, sample 21), belonging to the lower part of Sydorivska suite (bottom of the Upper Campanian) composed of light gray sandy marls there are microforaminifers of uncertain systematic association of the two types of spiral and spherical form with convoluted loculums. There are normal size and ferruginized foraminifera in this sample. The characteristic species of foraminifera: Cibicidoides aktulagayensis (Vass.), C. voltzianus (Orb.), Heterostomella foveolata (Marss.), H. praefoveolata Mjatl., Voloshinovella laffitei (Marie), Brotzenella monterelensis (Marie), B. menneri (Kell.), Pseudouvigerina cretacea Cushm., which indicate the Upper Campanian zone Brotzenella monterelensis [Стратиграфія..., 2013]. There are ostracod valves. The Campanian palynologacal complex is represented by Sphagnumsporites sp., Lycopodiunsporites sp., Osmundasidites sp., Todisporites sp., Matoniasporites spp., Lygodium- sporites sp., 
Coniopterius sp., Cyathidites sp., Alsophilla sp., Gleicheniidites laetus (Bolch.) Bolch., Plicifera delicate (Bolch.) Bolch., Ornamentifera echinata (Bolch.) Bolch., Pinus spp., Platysaccus sp., PoIlenites sp., Oculopollis sp., Gothanipollis sp., Nudopollis spp., Extratriporo-pollenites clarus Pfl., Extratriporo-pollenites perforates Zaklinskaja and dinocyst complex (typical: Odontochitina spp., Isabelidinium sp., Avellodinium sp., Aldorfia deflandrei (Clarke and Verdier) Stover and Evitt) and the remains of fossil fungi - conidia were found for the first time. It is the Upper Campanian according to macro- and microfauna [Стратиграфія..., 2013] and new palynological data.

In Campanian sediments, outcrop near the village of Heorhiyivka (Konoplyanka ravine, sample 42), Lugansk region, belonging to the lower part of Sydorivska suite (bottom of Upper Campanian) there are microforaminifers like Subtrochiliascia cf. cuvillieri Deak. In this sample we identified normal size foraminifera of Globorotalites emdyensis zone of Upper Campanian with a characteristic complex - Ataxophragmium crassum caspium Vass., Cibicidoides aktulagayensis (Vass.), C. voltzianus (Orb.), B. monterelensis (Marie), Globorotalites emdyensis Vass., Bolivinoides delicatulus Cushm. and lenticular foraminifera Pseudosiderolites muschketovi Zern. [Стратиграфія..., 2013]. There were found a shark tooth and ostracod shells. The Campanian palynological complex - Lycopodiunsporites sp., Osmundasidites sp., Matoniasporites spp., Lygodiumsporites sp., Coniopterius sp., Cyathidites sp., Gleicheniidites laetus (Bolch.) Bolch., Plicifera delicate (Bolch.) Bolch., Pinus spp., Platysaccus sp., PoIlenites sp., Oculopollis sp., Gothanipollis sp., Nudopollis spp., Extratriporo-pollenites perforates Zaklinskaja, and dinocyst complex - Aldorfia deflandrei (Clarke and Verdier) Stover and Evitt, Odontochitina costata Alb. and the appearance of Areoligera senonensis Lejeune-Carpentier were found for the first time. Previously described by macrofauna - Belemnitella langei langei Schatsk., Bostrychoceras polyplocum (Roem.) belong to the Upper Campanian according to macro- and microfauna [Стратиграфія..., 2013] and new palynological data.

In Maastrichtian sediments, borehole 97 (43.25 $\mathrm{m}$ and $47.25 \mathrm{~m}$ ), the East Sea of Azov, represented by dark gray sandy clay without carbonates (not showed in the scheme) there are microforaminifers Subtrochiliascia sp.,
Subknasteria cf. spiralis Macko, Subvalvulineria cf. nonioninoides Bandy, Subglobotruncana cf. lapparenti Brotz., Subglobotruncana cf. ventricosa White, Subglobotruncanita cf. stuarti (Lappar.), Subgyroidinoides cf. turgidus (Hag.), Subsherochorella cf. minuta (Tapp.), Subhemicyclammina cf. sigali Maync and uncertain systematic form of belonging. There are many fragments of microforaminifers with dissolved loculums and fragments of spherical and convoluted loculum forms. The form shown in Table IV, Fig. $10 a, b, c$ is similar to the form of Subtrochiliascia cf. cuvillieri Deak, but we have a piece of lining, Fig. 10 which seems the similar, but by needle in macerate we can see the forms in different projections, as the Fig. 10b and $10 \mathrm{c}$ show that the form is spiral. The loculums of such microforaminifers like a strung on a spiral. There are also found a lot of broken damaged forms, Table IV, Fig. 11, 12 in this sample, it may be the result of initial processing stage, which was associated with prolonged centrifugation. L.F. Plotnikova found the complex of normal size foraminifera in these deposits: Plectina ruthenica (Reuss), Cibicidoides cf. voltzianus (Orb.), Cibicidoides aktulagayensis Vass, Eponides conspectus Vass, indicating the Early Maastrichtian. The dinocysts Odontochitina spp., Odontochitina operculata (O. Wetzel) Deflandre et Cookson, Odontochitina costata Alberta emend. Clarke Verdier., Isabelidinium sp., Cerodinium sp. were found in these sediments for the first time. The dinocysts dominate, namely Spiniferites spp., Spiniferites ramosus (Ehrenberg) Mantell, Cleistosphaeridium spp., Cordosphaeridium sp., Oligosphaeridium sp. There are rare exemplars of Subtilisphaera sp., Hystrichodinium sp., Hystrichosphaeridium tubiferum (Ehrenberg) Deflandre, Operculodinium sp., Comparodinium sp., Achomosphaera sp., Deflandrea magna Davey, Cyclonephelium Willams et Downie. For the first time in the studied territory of Maastricht sediments there was found the palynological complex, represented by: Gleicheniidites laetus (Bolch.) Bolch., G. senonicus (Ross.) Grig., G. latifolius Doring, Lygodiumsporites subsimplex (Bolch.) Bolch. There is gymnosperms pollen: pollen grains Welwitschiapites sp., Araucariacites sp., Psophosphaera sp., coniferous pollen of Pinaceae and Podocarpaceae genera (Podpocarpus sp.). Pinaceous is represented by Piceae sp., Cedrus libaniformis Bolch., Pinus spp., Pinus vulgaris 
Naum., Pinus trivialis Naum., Pinus insignis Naum. Angiosperm pollen: Pollenites sp., Oculopollis sp., Nudopollis spp., Extratriporo-pollenites clarus Pfl., Extratriporo-pollenites vestifex Pfl., Basopollis aff. orthobasalis Pfl., Trudopollis spesiosus Zaklinskaja, Trudopollis nonperfectus Pfl., Trudopollis ordinates Zaklinskaja, Trudopollis pompeckji (R.Pot.) Pfl. The Maastrichtian deposits that are dark gray sandy clay without carbonates are described for the first time. According to systematic composition and percentage of microphytofossils in a complex the age of rocks can be dated as the Early Maastrichtian.

\section{Conclusions}

On the results of microforaminifers in macerates of Mesozoic sediments of Ukraine there are the following conclusions.

It is corrected the technique of initial processing of rock used for palynological analysis to extract microforaminifers from the Mesozoic rocks. It should be noted that the samples of carbonate rocks that have been treated with hydrochloric acid, in macerates contained nanoforaminifera linings which were quite brittle to the touch, and sometimes were destroyed. The samples of marl and alurite rocks, after treatment with hydrochloric and hydrofluoric acids contained in macerates the microforaminifers with pseudochitinous membranes possible to turn and touch, they suffered a slight strain, but not destroyed. So the hydrofluoric acid hardened the pseudochitinous membranes. The use of alternative methods of detection and determination of the taxonomic composition of Jurassic and Cretaceous microforaminifers substantially complement the characterization of foraminifera complexes of the studied area.

To classify the new forms we compared Jurassic and Cretaceous microforaminifers found in Ukraine with similar fossils studied by European, American and Russian scientists.

Since we were able to trace the distribution and diversity of microforaminifers from Callovian to Maastricht, we concluded that the most

\section{References}

1. Введение в изучение фораминифер: (Классификация мелких фораминифер мезокайнозоя) / под ред. Н.Н. Субботиной, Н.А. Волошиновой, А.Я. Азбель. Ленинград: Недра, 1981. 211 с. (М-во геологии СССР; ВНИГРИ).

Introduction of foraminifera into the study: (Classification of Meso-Cenozoic small foramini- rich in microforaminifers is Callovian, Aptian, Albian and Maastrichtian sediments, and by the lithology - argillaceous rocks. The pictures of microforaminifers are showed in four tables.

A clear stratigraphic association of microforaminifera complexes and the study of dinocysts and palynological complexes and foraminifera in the macerates allowed us to refine the stratigraphic confinedness to foraminifera units of Jurassic and Cretaceous sections of Ukraine. Sediments that are rich in normal size foraminifers not always contain a large number microforaminifers. The explanation for this may be the small size of these forms we call microforaminifers and meet in palynospectra as linings. But these forms are probably lost by microfaunists during the initial processing, as the size of the filter is much larger. Therefore, the microforaminifers complement the data for the study of normal size foraminifera. As the lining is marked primarily by palynologists, the collaborative work is essential. The percentage of coincidence microforaminifers with foraminifers of normal size is very small at a kind level.

The study of microforaminifers is valuable information for paleontologist-faunist as it allows studying the fauna from the outcrop deposits and wells and compare micro- and macrofaunal remains.

All our previous results will be refined in the future and supplemented with new data. The authors are grateful for the valuable suggestions of colleagues microfaunists L.F. Plotnikova and T.S. Ryabokon.

Microforaminifers are indicators of paleogeographic and paleoecological conditions changes. Thus, this group is used for paleogeographic reconstructions, Sea Basin temperature assessing, cycles of sedimentation and conditions of stagnation. With comprehensive study of different groups of flora and fauna: foraminifera, microforaminifers, dinocyst, acritarchs and prasinophytes allow us to make a number of assumptions on paleobionomic conditions of sedimentation basin.

fera), 1981. (Eds. N.N. Subbotin, N.A. Voloshinova, A.Ya Azbel). Leningrad: Nedra, 211 p. (Ministry of Geology of the USSR; All-Union Geological Oil Exploration Institute) (in Russian).

2. Глузбар Э.А. Псевдохитиновые ископаемые «микрофораминиферы» в палинологических 


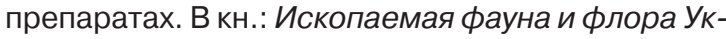
раины. Киев: Наук. думка, 1983. С. 28-31.

Gluzbar E.A., 1983. Pseudochitinous fossil «microforaminifers» in palynological specimen. In: The fossil fauna and flora of Ukraine. Kiev: Naukova Dumka, p. 28-31 (in Russian).

3. Доротяк Ю.Б., Матвеев А.В., Шевчук Е.А. Характеристика пограничных отложений юры и мела в Горном Крыму (фораминиферы, известковый наннопланктон, диноцисты, палинокомплексы). Зб. наук. пр. Ін-ту геол. наук НАH України «Викопна фауна і флора України: палеоекологічний та стратиграфічний аспекти». Київ, 2009. С. 108-117.

Dorotyak Yu.B, Matveyev A.V., Shevchuk O.A., 2009. Characteristics of Jurassic and Cretaceous boundary sediments in the Crimean Mountains (foraminifera, calcareous nannoplankton, dinocysts, palynocomplexes). Collection of Scientific Works of the Institute of Geological Sciences of NAS of Ukraine "The fossil fauna and flora of Ukraine: paleoecological and stratigraphic aspects». Kyiv, p. 108-117 (in Russian).

4. Лебедева Н.К., Никитенко Б.Л. Микрофитопланктон и микрофораминиферы опорного разреза нижнего мела Приполярного Зауралья. Геология и геофизика. 1998. Т. 39. С. 799-820.

Lebedeva N.K., Nikitenko B.L., 1998. Microphytoplankton and microforaminifers of Lower Cretaceous section of Subpolar Zauralye. Geologiya $i$ Geofizika, vol. 39, p. 799-820 (in Russian).

5. Методические рекомендации к технике обработки осадочных пород при спорово-пыльцевом анализе: сост. И.В. Петрова и др. Ленинград, $1986.77 \mathrm{c.}$

Guidelines to the technique of processing of sedimentary rocks on spore-pollen analysis, 1986. (Compiled by I.V. Petrova et al.). Leningrad, $77 \mathrm{p}$. (in Russian).

6. Никитенко Б.Л., Глинских Л.А. Микрофауна келловея и верхней юры Тюменской сверхглубокой скважины (Север Западной Сибири). Новости палеонтологии и стратиграфии. (Приложение к журналу «Геология и геофизика»). 2006. Т. 47, вып. 9. С. 77-95.

Nikitenko B.L., Glinskikh L.A., 2006. Callovian and Upper Jurassic microfauna of Tyumen ultradeep well (North West Sibiori). News of paleontology and stratigraphy. (Supplement to the journal «Geology and Geophysics»), vol. 47, iss. 9, p. 77-95 (in Russian).

7. Основы палеонтологии. Справочник для палеонтологов и геологов СССР. Общая часть. Простейшие / отв. ред. тома Д.М. Раузер-Черноусова, А.В. Фурсенко. Москва: Изд-во АН CCCP. 1959. 482 c.
Basics of paleontology. Handbook for paleontologists and geologists of the USSR. The general part. Protozoa, 1959. (Ed. D.M. Rauser-Chernousova, A.V. Fursenko). Moscow: Izdatelstvo AN SSSR, 482 p. (in Russian).

8. Петросьянц М.А., Овнатанова Н.С., Мусина Г.В. Микрофоссилии в геологической практике: их роль в определении обстановок древнего осадконакопления. Москва, 1990. Т. 27. 163 с. (Итоги науки и техники. Сер. Общая геология).

Petrosyants M.A., Ovnatanova N.S., Musina G.V., 1990. Microfossils in geological practice: their role in determining the ancient depositional environments. Moscow, vol. 27, 163 p. (Results of science and technology. Series General Geology) (in Russian).

9. Стратиграфія верхнього протерозою та фанерозою України. Т. 1. Стратиграфія верхнього протерозою, палеозою та мезозою України / гол. ред. П.Ф. Гожик. Київ: Логос, 2013. 637 с.

Stratigraphy of Upper Proterozoic and Phanerozoic of Ukraine. Stratigraphy of Upper Proterozoic, Paleozoic and Mesozoic of Ukraine, 2013. (Ed. P.F. Gozhyk). Kyiv: Logos, vol. 1, 637 p. (in Ukrainian).

10. Федорова А.A. Комплексное применение методик изучения мезозойских фораминифер в шлифах и препаратах на примере позднеюрскихраннемеловых фораминифер Горного Крыма В кн.: Меловая система России и ближнего зарубежья: проблемы стратиграфии и палеогеографии: Сб. науч. тр. / под ред. Е.М. Первушова. Саратов: Изд-во Сарат. ун-та, 2006. С. 143-144.

Fedorova A.A., 2006. Complex application of techniques for studying Mesozoic foraminifera in thin sections and specimens on the example of the Late-Early Cretaceous foraminifera of the Crimean Mountains. In: Cretaceous System in Russia and abroad: problems of stratigraphy and paleogeography: Collection of Scientific Works. (Ed. E.M. Pervushov). Saratov, p. 143-144 (in Russian).

11. Фуртес В.В. Микрофораминиферы из осадочных отложений Белокоровичской грабен-синеклизы. Геол. журн. 1987. Т. 47, № 3 (235). С. 96-98.

Furtes V.V., 1987. Microforaminifers of Belokorovichskaya graben-syncline sediments. Geologicheskiy zhurnal, vol. 47, № 3 (235), p. 96-98 (in Russian).

12. Чорна О. Палиноморфы из меловых конкреций зоны утесов Западных Карпат. Geologica Carpathica. 1972. Vol. 23, № 1. P. 173-196.

Chorna O., 1972. Palynomorphs of chalk nodules of cliff zones of the Western Carpathians. Geologica Carpathica, vol. 23, № 1, p. 173-196 (in Russian).

13. Шевченко Т.В. К методике извлечения микрофитофоссилий из пород песчано-глинистой группы. Альгология. 2006. Т. 16, № 3. С. 395-399. 
Shevchenko T.V., 2006. On the method of extraction of microphytofossils from the rocks of sandclay group. Algologiya, vol. 16, № 3, p. 395-399 (in Russian).

14. Шевчук О.А. Динофитовые водоросли из меловых отложений северо-западной Украины (Волынь). Зб. наук. пр. Ін-ту геол. наук НАН України «Проблеми біостратиграфії нижнього протерозою і фанерозою України». Київ, 2006. С. 118-123.

Shevchuk O.A., 2006. Dinoflagellates from Cretaceous sediments of north-western Ukraine (Volyn). Collection of Scientific Works of the Institute of Geological Sciences of NAS of Ukraine «Problems of biostratigraphy of Lower Proterozoic and Phanerozoic of Ukraine». Kyiv, p. 118-123 (in Russian).

15. Шевчук O.A. Палінологічне обгрунтування стратиграфічного розчленування крейдових відкладів Гірського Криму. Зб. наук. пр. Ін-ту геол. наук НАН України. 2009. Вип. 2. С. 223-234.

Shevchuk O.A., 2009. Palynological justification of stratigraphic differentiation of Cretaceous sediments of Crimean Mountains. Collection of Scientific Works of the Institute of Geological Sciences of NAS of Ukraine, vol. 2, p. 223-234 (in Ukrainian).

16. Шевчук O.A. Dinocysts из келловейских отложений центральной Украины. Альгологія. 2012. T. 22, № 4. C. 410-418.

Shevchuk O.A., 2012. Dinocysts of Callovian deposits of central Ukraine. Algologiya, vol. 22, № 4, p. 410-418 (in Russian).

17. Cohen A.D., Guber A.L. Production of pollen sized «microforaminifera» from «normal» foraminifera. Micropaleontology. 1968. Vol. 14, № 3. P. 361-362.

Cohen A.D., Guber A.L., 1968. Production of pollen - sized «microforaminifera» from «normal» foraminifera. Micropaleontology, vol. 14, № 3, p. 361362 (in English).

18. Deak M.H. Les Scytinascia. Bulletin de la Societe Geologique de Hongrie. 1964. Vol. 94, № 1. P. 95-106.

Deak M.H., 1964. Les Scytinascia. Bulletin de la Societe Geologique de Hongrie, vol. 94, № 1, p. 95-106 (in France).

19. Loeblich A.R., Jr., and Tappan H. Foraminiferal genera and their classifications. I. Foraminifera - Classification. II. Title. - Van Nostrand Reinhold Company. New York (2 vols.), 1988. 2047 p.

Loeblich A.R., Jr., and Tappan H., 1988. Foraminiferal genera and their classifications. I. Foraminifera - Classification. II. Title. - Van Nostrand Reinhold Company. New York (2 vols.), 2047 p. (in English).

20. Lantos M., Wagreich M., Siegl-Farkas A., Bodnar E., Csaszar G. Integrated stratigraphic correlation of the Upper Cretaceous sequence in the borehole Bakonyjako 528 / Advances in Austrian Hungarian Joint Geological Research. Budapest, 1996. P. 97-117.

Lantos M., Wagreich M., Siegl-Farkas A., Bodnar E., Csaszar G., 1996. Integrated stratigraphic correlation of the Upper Cretaceous sequence in the borehole Bakonyjako 528 / Advances in Austrian Hungarian Joint Geological Research. Budapest, p. 97-117 (in English).

21. Mikk M., Sotak J. Microforaminifers a specific fauna of organic-walled foraminifera from the Callovian-Oxfordian limestones of the Pieniny Klippen Belt (Western Carpathians). Geologica Carpathica. 1998. Vol. 49, № 2. P. 109-123.

Mikk M., Sotak J., 1998. Microforaminifers a specific fauna of organic-walled foraminifera from the Callovian-Oxfordian limestones of the Pieniny Klippen Belt (Western Carpathians). Geologica Carpathica, vol. 49, № 2, p. 109-123 (in English).

22. Pantic N., Bajraktarevic Z. Nannoforaminifera in palynological preparations and smear-slides from Mesozoic and Tertiary deposits in central and southeast Europe. Revue de Paleobiologie, Suppl. Volume special. 1988. № 2 (2). P. 953-959.

Pantic N., Bajraktarevic Z., 1988. Nannoforaminifera in palynological preparations and smear-slides from Mesozoic and Tertiary deposits in central and southeast Europe. Revue de Paleobiologie, Suppl. Volume special, № 2 (2), p. 953-959 (in English).

23. Stancliffe R.P.W. Microforamiferal linings. In: Jansonius, J. \& McGregor, D.C. (Eds.), Palynology: principles and applications; American Association of Stratigraphic Palynologists Foundation, 1: 1996. P. 373-379.

Stancliffe R.P.W. Microforamiferal linings. In: Jansonius, J. \& McGregor, D.C. (Eds.), Palynology: principles and applications; American Association of Stratigraphic Palynologists Foundation, 1: 1996, p. 373-379 (in English).

24. Wetzel O. Fossil «microforaminifera» in various sediments and their reaction to scid treatment. Micropaleontology. 1957. Vol. 3, № 1. P. 61-64.

Wetzel O., 1957. Fossil «microforaminifera» in various sediments and their reaction to scid treatment. Micropaleontology, vol. 3, № 1, p. 61-64 (in English).

25. Wilson L.R., Hoffmeister W.S. Small foraminifera. Micropaleontology. 1952. Vol. 6, № 2 . P. 26-28.

Wilson L.R., Hoffmeister W.S., 1952. Small foraminifera. Micropaleontology, vol. 6, № 2, p. 2628 (in English).

Received

February 18, 2015 